\title{
Out-migration, depopulation and the geography of U.S. economic distress
}

\author{
by \\ Edward Feser \\ Assistant Professor \\ Department of City \& Regional Planning \\ CB 3140, New East Building \\ University of North Carolina \\ Chapel Hill, NC 27599-3140 \\ Voice:919-962-4762 \\ Fax:919-962-5206 \\ Email:feser@email.unc.edu \\ and \\ Stuart Sweeney \\ Assistant Professor \\ Department of Geography \\ University of California \\ Santa Barbara, CA 93106-4060 \\ Voice: $805-893-5647$ \\ Fax: 805-893-3146 \\ Email: sweeney@geog.ucsb.edu \\ Forthcoming \\ International Regional Science Review
}

Revised January 2002 


\title{
Out-migration, depopulation and the geography of U.S. economic distress
}

\begin{abstract}
This paper uses data for various years over the 1969-99 period to examine the spatial extent and temporal persistence of U.S. economic distress as viewed by three different indicators: unemployment, low income, and out-migration induced population decline. The basic unit of analysis is the commuter zone. The shifting geography of distress is summarized for the four Census regions and three regions of traditional economic development concern: Appalachia, the Mississippi Delta, and the Great Plains. The research grew out of an effort to assist the U.S. Economic Development Administration (EDA) in an internal review of criteria used to target development assistance. EDA was concerned that it may be neglecting distress associated with out-migration induced population decline; i.e. that some regions in the U.S. may be deserving of development aid even if their level of distress appears moderate based on the agency's two traditional core criteria: low income and high unemployment. We address the practical and theoretical issues associated with out-migration induced population decline as a type of economic distress and comment on the development priorities implied by each of the three indicators.
\end{abstract}




\section{Out-migration, depopulation and the geography of U.S. economic distress}

\section{INTRODUCTION}

The official reauthorization of the U.S. Economic Development Administration (EDA) in February 1999 represents a substantial achievement for an agency that has been under the near constant threat of abolishment since its inception in 1965. The federal government's commitment to the development of distressed regions has been effectively re-affirmed, at least temporarily. To implement Public Law 105-393, the amendment to the founding Public Works and Economic Development Act, EDA undertook a substantial revision of its regulations, including a review of its area eligibility criteria for its two largest programs, Public Works grants and Economic Adjustment assistance. One important focus of the review was on out-migration and population loss as potential indicators of economic distress. Congressmen and development officials from slow-growing states were questioning whether EDA was neglecting distress associated with out-migration induced population decline; i.e. that some regions in the U.S. may be deserving of development aid even if they fail to qualify for assistance based on the agency's two traditional core distress criteria: low income and high unemployment (Feser and Sweeney 1998). The issue is acute for states such as Maine, Mississippi, and North and South Dakota. EDA's internal evaluation speaks generally to the question of proper economic distress measurement for the purposes of targeting scarce development resources. In addition to EDA, a number of federal and state agencies identify and target distressed areas for special programs, including the Department of Agriculture (USDA), the Department of Housing and Urban Development (HUD), the Federal Emergency Management Agency, the Bureau of Indian Affairs, Tennessee Valley Authority (TVA), and the Appalachian Regional Commission (Glasmeier and 
Fuellhart 1999; Wood and Bischak 1999). In a review of sixteen federal and eighteen state programs, Fullenbaum and McNeill (1995) found that the most common distress measures are unemployment, poverty, and income. Six of the sixteen federal programs consider population change or out-migration as indicators of distress, in all cases in concert with other measures such as poverty and unemployment. In most programs, absolute criteria are applied; i.e. a minimum or maximum level of an indicator must be achieved for an area to be considered distressed. Some programs (including several HUD, USDA, and TVA initiatives) adopt a relative standard on given indicators (i.e., a city, county, or region effectively qualifies for aid based on its rank on selected distress measures).

Distress measurement with respect to migration is a thorny problem that raises fundamental issues about the process of regional growth and change. On the one hand, neoclassical growth models see migration and population change as the central means by which regions adjust to economic shocks; out-migration and population decline essentially presage recovery as the labor supply adjusts to contractions in demand (Borts and Stein 1964, McCombie 1988a). Tangible forms of distress like persistent unemployment and poverty suggest a failure to adjust, perhaps as a result of wage rigidities or impediments to migration. The policy implication is that programs should facilitate, if not actively encourage, population adjustment in areas of high unemployment or low income. On the other hand, cumulative causation theories and variants of the newer endogenous regional growth theory suggest that migration itself may impede recovery by depleting a region of its best and brightest (Clark, Gertler and Whiteman 1987, McCombie 1988b). It is well-known that migration is a highly selective process, with younger, better educated, and higher skilled workers moving first in response to economic decline (Sjaastad 1962, Kwok and Leland 1982, Bronars and Trejo 1992). The cumulative 
causation view originating with Myrdal (1957) implies that it is appropriate to focus development resources on places facing high rates of out-migration and population decline if there is a risk that such demographic trends will engender a sustained downward economic spiral.

This paper does not generate direct evidence of a link between out-migration and regional economic well-being. Rather, it asks a simpler but generally neglected question: namely, whether the incidence and geography of out-migration induced population decline are such that serious policy attention is even warranted. The problem of out-migration might be a non-issue for all practical purposes if 1) comparatively few places experience rapid out-migration in conjunction with population decline in any given period, 2) few regions post high rates of outmigration and population decline in the absence of traditional forms of distress, and 3) such high out-migration places that do not also face traditional kinds of distress are spread evenly over the landscape, so that no single area of the country is disproportionately neglected by programs that ignore out-migration trends in their allocation schemes. We explore these questions in the context of a broader analysis of economic distress trends over the last three decades using an extensive series of annual county-to-county migration data from the Internal Revenue Service, income and population data from the Bureau of Economic Analysis, and local area unemployment statistics from the Bureau of Labor Statistics.

The following section describes our data and methodology. The subsequent section examines the geography of population decline/out-migration, unemployment, and low income for the 722 commuter zones of the contiguous U.S. To our knowledge, there is no existing comprehensive study of the geography of distress for functional economic areas, which commuter zones approximate. Most studies are for counties, usually within a specific service area (e.g. Appalachia, see Glasmeier and Fuellhart 1999 and Wood and Bischak 1999). The final 
section discusses the findings in relation to EDA's resource allocation process, the general spatial targeting of federal and state development programs, and the regional spatial structure of the U.S.

\section{METHODS AND DATA}

In evaluating the incidence and geography of out-migration and population decline in the U.S., we face four major issues: 1) the choice of areal unit of analysis; 2) the choice of variables, both for out-migration as well as comparison indicators of distress; 3) the choice of absolute versus relative measures of distress; and 4) the choice of time period. Our methods for dealing with each issue are based on one overriding objective: to develop a consistent means of tracking economic distress over time and space that permits valid comparisons across measures. In the remainder of the paper, we use the term "distress" to describe high rates of out-migration induced population decline only for convenience. As we note above, whether out-migration and population decline contribute to or alleviate distress remains a matter of dispute in the literature.

\section{Unit of Analysis}

The usual units of analysis in studies of the geography of distress are counties, mainly because most programs are administered at the county level or for regions that are constructed from counties. But counties are inappropriate for tracking out-migration and population change since intra-metropolitan population shifts are significant enough in some regions of the country to distort the out-migration picture within relatively self-contained regional economies; considerable intra-regional out-migration is observed for some high growth regions. Therefore, we use commuter zones as the areal unit. Commuter zones, developed by the USDA's Economic Research Service from 1990 Census data, are mutually exclusive and exhaustive aggregates of counties with strong commuting ties. As such, they approximate functional economic areas. While commuter zones based on 1990 data may not perfectly reflect economic regions for earlier 
and later periods, they do have the advantage of holding geography constant over the period of analysis. The 1990 commuting data are also reasonably close to the mid-point (1983/4) of our longest series.

There are 741 commuter zones across the 50 states and District of Columbia, 722 in the contiguous 48 states. We restrict our analysis to the 722 zones of the lower 48 states for two reasons. First, migration dynamics for Alaska and Hawaii are unique relative to the rest of the U.S. given those states' isolation and unique economies. Second, much of the data for Alaska and Hawaii suffer from anomalies that prevent the construction of consistent economic indices by commuter zone (e.g. areal reporting schemes that are difficult to reconcile across data series, as in the case of Alaska, or missing data for small units, as in the case of both states).

We summarize our findings for commuter zones at a higher level of geography: the four Census Regions (Northeast, Midwest, South and West, the latter excluding Alaska and Hawaii) and three traditional areas of regional development concern (the Great Plains, the Lower Mississippi Delta, and Appalachia). Our classifications of Plains, Delta, and Appalachian commuter zones are based on the following: for the Plains, a roughly 450 county area defined by the Population Research Center of the University of Texas at Austin from data on relevant natural conditions (general topography, elevation, and geography); for the Delta, a 219 county designation adopted by the President's Lower Mississippi Delta Development Commission; and 3) for Appalachia, the current 406 county service area of the ARC. Note that there is some overlap between the Delta and Appalachian regions while the four Census Regions are mutually exclusive. Table 1 reports the total number of commuter zones in each area along with population figures for 1969 and 1998.

[Table 1 near here] 


\section{Economic Indicators}

We compare geographic trends in out-migration and population decline to two of the most common distress indicators used to target development aid: low income and unemployment. We exclude the poverty rate, another typical indicator of distress, since poverty rates for sub-state areas are unavailable on a year-by-year basis. Unemployment is expressed as a rate and low income as the ratio of income maintenance transfer payments (for family assistance, food stamps, and other income maintenance programs) to total personal income.

It is worth considering in some detail why we elect to use the ratio of income maintenance payments to income rather than simple per capita income. The latter is problematic for studying the geography of distress because of significant differences in rates of inflation and cost-of-living over space. An additional issue is that our unemployment and outmigration/depopulation measures are both expressed as rates. Rates have the advantage of facilitating the setting of defensible distress thresholds that can be held constant over time. Per capita income, on the other hand, is a levels variable that has steadily increased over time in most regions. It is therefore more difficult to set a per capita income distress threshold that facilitates comparisons of the incidence of distress over both time and space. Unemployment data (19771999) are from the Bureau of Labor Statistics while income data (1969-1998) are from the Bureau of Economic Analysis' Regional Economic Information System.

Rather than calculate simple out-migration rates or rates of net population growth singly, we distinguish high growth/high out-migration places from places experiencing high outmigration/depopulation with the following measure of out-migration/population loss (OPL):

$$
\mathrm{OPL}_{\mathrm{it}}=\left(\frac{\mathrm{O}_{\mathrm{it}}}{\mathrm{P}_{\mathrm{it}}^{*}}\right)\left(\frac{\mathrm{P}_{\mathrm{i}, \mathrm{t}+1}-\mathrm{P}_{\mathrm{it}}}{\mathrm{P}_{\mathrm{it}}}\right)
$$


where $i$ and $t$ index regions and year, respectively, $O$ is the number of out-migrants as reported by the Statistics of Income Division of the Internal Revenue Service (IRS), $P^{*}$ is estimated population from the IRS, and $P$ is population from the Bureau of Economic Analysis. The IRS migration data, the only year-by-year migration flows available for sub-state areas, are based on the number of exemptions reported on tax returns for which a change of address is indicated. As the product of the out-migration rate and the rate of population change, OPL decreases (takes large negative values) the higher the rates of population decline and out-migration; high rates of out-migration and population increase give the indicator a high positive value. OPL is therefore capable of distinguishing high growth places with high rates of population turnover from regions subject to significant out-migration and depopulation. At the time of this writing, IRS migration data were available for the years 1984/5-1997/8.

A limitation of OPL is that regions with low rates of population decline and high rates of out-migration technically cannot be distinguished from those with high rates of population decline and low rates of out-migration. However, this problem is mitigated by two factors. First, the case where the population loss is very high and out-migration is low is rare in developed economies. That would only occur with a spectacularly high rate of natural decrease (characteristic of war, disease, or famine). Even in areas with skewed age distributions and a large proportion of elderly, the effect of the rate of natural decrease on OPL is small relative to the overall distribution. Second, we are mainly interested in places with very high negative rates of OPL (where the problem is extreme). Such places overwhelming post above average rates of both population decline and out-migration.

While IRS returns data can be an extremely useful source of information on interregional migration, they have to be used cautiously (Isserman, Plane, and McMillan 1982). Because not 
all households file federal tax forms for a variety of reasons, and because of non-compliance with federal laws pertaining to exemptions, IRS data may yield biased estimates of interregional population flows. However, given that there is little reason to expect a geographic bias in reporting or compliance, the IRS data provide a reasonable proxy for migration rates or overall patterns of system interaction. They have the added advantage of substantial regional disaggregation (to the county level), permitting the construction of data for functional economic units such as commuter zones.

\section{Absolute vs. Relative Distress}

In a general sense, regional policy priorities may be defined as supporting either a relative or absolute notion of development. A focus on reducing interregional disparities in key economic indicators (the question of regional convergence/divergence) is essentially a relative view of development, since the concern is with equalizing key indicators even if overall levels of development have been achieved. A focus on attaining some absolute level of economic development in all regions-say in terms of population or employment, for example-without regard for convergence, per se, is an absolute view.

These priorities relate directly to the appropriateness of various distress measures. For example, what degree of unemployment or low income should classify a region as economically distressed? EDA policy holds that regions posting an unemployment rate one percentage point above the average national rate for the preceding two year period are distressed, regardless of the absolute level of unemployment nationwide (which, as we saw in 2000, could be as low as 3.5 percent). This is clearly a relative view (and one that admittedly has as much to do with the politics of federal resource allocation as it does with legitimate notions of distress). Alternatively, clear thresholds that would admit the possibility that distress could eventually be 
eliminated for most if not all U.S. regions might also be defined, an absolute view of development. In practice, not only are economic series moving targets (e.g. the nonaccelerating inflation rate of unemployment, which might serve as a basis for an absolute unemployment distress threshold, is not constant over the long run), making absolute threshold definition difficult, but one can make a good case that distress is both a matter of relative position vis-á-vis other regions as well as a situation of absolute deprivation or hardship (Sen 1999).

Because we are interested in the spatial distribution of distress over long periods that encompass shorter cycles of growth and recession, we adopt an approach that is essentially a hybrid of absolute and relative distress measurement. Namely, we identify thresholds with respect to each indicator's full annual regional series. For example, our unemployment rate distress threshold, 8.4 percent, is the $75^{\text {th }}$ percentile from the global distribution of 22 years of unemployment data for each contiguous U.S. commuter zone (nearly 16,000 data points). For any given variable, our standard is relative to the time period in question (in the case of unemployment, 1977-1999) but absolute on a year-by-year basis within the period, thereby placing distress in a longer-run perspective: while an 8.4 percent unemployment rate is quite high from the point of view of the 1990s expansion, it is relatively modest in the context of the mid1970s and early 1980s recessionary periods. ${ }^{1}$

If we adopted a year-by-year standard (similar to the EDA's), then the early 1980s would see us identifying regions as distressed only if they posted rates of 10.5-11.5 percent or more while the late 1990s would see regions characterized as distressed if their unemployment rates exceeded the comparatively low 4.5-5.5 percent. That would artificially underestimate the spatial incidence of realistic distress in the early to mid-1980s while arguably overestimating the incidence in the late 1990s. Over the longer haul of the last three decades, a strong majority of 
regions in most individual years posted unemployment rates well below 8.4 percent. Regions with rates above 8.4 percent in any given year were clearly distressed in absolute and relative terms from this historical perspective. We define our low income threshold similarly: the $75^{\text {th }}$ percentile for the ratio of income maintenance payments to income. The OPL threshold is set at the $25^{\text {th }}$ percentile since low values indicate more out-migration induced population decline. We could, of course, adopt looser or stricter standards (higher or lower percentiles, as the case may be); our choice is essentially a matter of judgement for the purposes of highlighting regional patterns over time.

\section{Time Period}

As we show below, the geography of U.S. economic distress changes substantially over time as places adjust differently to various national and regional shocks and expansions. Such changes are not as apparent when indicators are averaged over multiple years or differenced for arbitrary periods (e.g. five or ten year changes). At the same time, annual data are difficult to interpret. Therefore, we examine distress for economically meaningful periods or "epochs," including the post mid-1970s recession through the early 1980s recession, the post-1982 recession through the early 1990s recession, and the historic expansion of the mid- to late-1990s. Each of those periods were characterized by substantial and arguably unique kinds of restructuring, technological change, and/or shifts in business strategy that had, in many cases, distinct regional impacts (e.g., the heavy restructuring of the manufacturing belt in the 1970s and early 1980s, the farm and mining crises of the 1980s, and the rapid growth of high tech industries in combination with contractions in defense spending in the 1990s). Because knowing something about the persistence of distress in particular regions is important from the perspective of development policy, we also characterize the geography of distress in terms of the distribution 
of zones that remain distressed for long periods. The annual series, summarized for different economic periods, paint a detailed portrait of the changing spatio-economic conditions in the U.S. while the analysis of persistence provides some indication of how quickly certain regions adjust to economic shocks.

\section{OUT-MIGRATION, DEPOPULATION, AND THE SPATIAL PATTERN OF U.S. ECONOMIC DISTRESS}

Over the last thirty years of the twentieth century, economic distress shifted across the landscape, clinging persistently to some places while touching others only temporarily. Given our use of absolute thresholds, few regions escaped at least a modest degree of distress in some periods (e.g., during the recessionary years of the 1980s). Nevertheless, the majority adjusted relatively quickly to shocks through a combination of economic resurgence and population change. Trends in population decline and out-migration, unemployment, and low income over the last thirty years reveal, among other things, a gradual shift in the geography of overall distress to the high growth West and South, prolonged income distress in the Appalachia and the Delta, a rapidly adjusting Plains with little sustained income or unemployment distress over any subperiod, comparatively few regions with high rates of out-migration and population loss in the absence of some other form of distress, and a pattern of out-migration and population decline characteristic of the Plains but uncommon in other parts of the country. Below we show that while the out-migration/population loss problem has historically generally been a small one in terms of affected population, it is highly localized in spatial extent. As we suggested above, that turns out to have important policy implications. 


\section{Distress at the End of the 1990s}

Near the close of the millennium-and before the slowdown of late 2000 and early 2001-the picture with respect to regional economic distress in the U.S. was mixed. On the one hand, unemployment distress was approaching historic lows. In 1999, just 52 commuter zones (about 7 percent of all contiguous U.S. zones) were unemployment-distressed according to our threshold, with the group posting a median unemployment rate of 9.5 percent (see Table 2). That was down considerably from a decade high of 218 zones (and a median rate of 10.1 percent) in 1992 and a 23-year high of 440 zones in 1983 (with a median unemployment rate among distressed zones of 11.7 percent). In 1998, the latest year for which population data were available at the time of this writing, only 3.4 percent of the population of the contiguous U.S. resided in unemployment distressed zones, compared to 28.4 percent in 1992 and 62.6 percent in 1983, the peak of the worst recession of the full period. The share of U.S. zones unemploymentdistressed in each period is plotted in Figure 1 against the OPL and income indicators. Also plotted in the figure is the share of zones posting population losses.

[Table 2 and Figure 1 near here]

On the other hand, while income distress was showing signs of falling from mid-1990s highs, it remained above levels of distress posted in the 1970s and 1980s. Some 224 zones (onethird of the total) fell below our income-distress threshold in 1998, down from a decade peak of 269 zones in 1996. However, the number of income distressed zones has steadily increased over the last thirty years, from an average of 151 in the 1970s to averages of 165 and 236 in the 1980s and 1990s, respectively. Given our methodology for setting a distress threshold, the trend might be explained by the gradual expansion of the general social safety net and increasing knowledge of available programs (and thus increased applications for support). Indeed, the lowest number 
of income-distressed zones between 1969 and 1998 occurred in 1969 (a total of 90 zones). But while these trends likely play a role, particularly in the 1970s and 1980s, growth in the ratio of income maintenance payments to income requires that the growth rate of income maintenance support outpaces the rate of growth in general personal income. That is surely a sign of something amiss in the given regional economy and perhaps more generally in the U.S. There is evidence that income inequality has worsened in the U.S. during the 1990s and the maps presented here may be a spatial manifestation of that trend (Bernstein et al. 2000). Overall, the geographical pattern of income distress as measured by the transfer payments ratio is in close accord with our prior understanding of areas of significant economic distress in the U.S. Thus, we believe it does a reasonably good job of tracking income-related distress over time and space. Unemployment distress at the end of the 1990s was primarily a southern and western phenomenon, with the South and West regions together accounting for 92 percent of distressed zones in 1999. The two regions also faced the greatest degree of relative distress: 15 and 9 percent of all Western and Southern zones, respectively, were unemployment-distressed in 1999, compared to roughly 5 percent of zones in the Northeast and less than 1 percent in the Midwest. The picture of distress generated by counting commuter zones in each broader region is imperfect because of the different sizes of the zones (larger in the West, smaller in the East) as well as differences in population densities. But if we tally the populations of distressed zones, the concentration in the West and South is even more pronounced. ${ }^{2}$ Indeed, the two regions account for 96 percent of the total 48-state distressed zone population in 1999. Among the three traditional development regions, the Mississippi Delta faced the greatest relative unemployment distress at 12 percent of its commuter zones (though just 7 zones in total). In the Plains, just four 
zones (less than 3 percent of all Plains zones) were unemployment-distressed in 1999 by our threshold, although those four zones held 17 percent of the Plains' population.

[Figure 2 near here]

Figure 2 displays the degree of unemployment distress by zone, distinguishing between commuting sheds posting unemployment rates in the $75^{\text {th }}$ to $90^{\text {th }}$ percentile (between 8.4 and 11.0 percent; the lighter shade) and $90^{\text {th }}$ to $100^{\text {th }}$ percentile (over 11.0 percent; the darker shade) of the 22 year distribution. It depicts the most distressed regions in the contiguous U.S. in 1999 in the context of the historical pattern of regional unemployment distress over the 1977 to 1999 period. $^{3}$ Also delineated are the boundaries of the Great Plains, Delta, and Appalachian regions; we leave off the Census region boundaries both to simplify the map and because they are well-known. High unemployment rates are concentrated in the heart of Appalachia (central and southern West Virginia and eastern Kentucky), in the Delta in west central Mississippi and northern Louisiana, along the U.S.-Mexico border, among the Native American territories of Arizona and New Mexico, in the agricultural Central Valley of California, in resource-intensive northern California and south central Oregon, and in eastern Washington, northern Idaho, and far western Montana. Figure 2 can be compared to Figure 3, which was produced using a threshold based on the distribution of distress relative to 1999 alone, namely the EDA's criterion of one percentage point above the national rate of unemployment for the most recent 24 month period (roughly 4.4 percent). No major additional larger regions of unemployment distress are revealed in Figure 2; the map mainly highlights the geographic extensiveness of the severe unemployment problems of eastern Oregon and Washington, the U.S.-Mexico border, and Appalachia and the Delta.

[Figure 3 near here] 
The regional pattern of income distress at the end of the century was broadly similar to that of unemployment, though the concentration in the South was much more pronounced. In general, income distress is more prevalent nationwide as well as more persistent (as we show below). Some 55 percent of Southern commuter zones (150 in total) were classified as distressed in 1998 according to our threshold, compared to 28 percent in the West, 19 percent in the Northeast, and 9 percent in the Midwest. In the Mississippi Delta, 66 percent of zones were income-distressed in 1998, over twice the national average of 31 percent. In Appalachia and the Great Plains, a respective 43 and 25 percent of zones were income-distressed in 1998. Figure 4 maps the distribution of income-distressed zones. A comparison to Figure 2 indicates that while income and unemployment distress tend to go hand in hand along the West Coast, that is not the case in the South, particularly in the Texas panhandle, lower Mississippi Delta, Gulf Coast region (including the Florida panhandle), and east of the Appalachian region (along a belt that includes southeastern Georgia, eastern North and South Carolina, and southeastern Virginia). In the South, while unemployment is confined to a few sub-regional pockets at the end of the 1990s, reliance on welfare and other income maintenance programs remains comparatively extensive, perhaps reflecting the continued prevalence of low-wage jobs in both the manufacturing and services sectors in the region.

\section{[Figure 4 near here]}

The regional pattern of rapid out-migration and population decline at the end of the 1990s differs considerably from that of low income and unemployment. It is nearly exclusively a problem of the Great Plains, though it touches part of the Northeast (particularly upstate New York and northern Maine) as well. Some 157 zones were classified as distressed according to our OPL index for 1998, 77 of those in the Midwest and 36 in the West (the two Census regions 
that encompass parts of the Plains). One-third of Northeastern zones (13 in total) were OPLdistressed as well. Over the period 1985 to 1998 , OPL distress peaked in 1987 at 308 zones, fell to a low of 62 zones in 1994, and rose steadily from 1994 to 1998. Over half of the Plains zones were OPL-distressed in 1998, compared to 14 percent of zones in the Delta and 11 percent of zones in Appalachia. Figure 5 highlights the concentration of OPL-distress in the Great Plains, as well as smaller pockets in Idaho, eastern California, south central Oregon, New York, Pennsylvania, and Maine.

[Figure 5 near here]

With this picture of the current state of regional economic distress in place, we now highlight several major trends in regional unemployment, low income, and out-migration induced population decline over the last 25 to 30 years. Our aims are to characterize the changing spatial distribution of distress, the general relationships between distress indicators, the persistence of different kinds of distress, and the geographic extensiveness of the out-migration/population decline problem. In so doing, we also provide an indirect descriptive characterization of differences in regional adjustment patterns.

\section{Unemployment Distress Shifting South and West}

Even over the comparatively short 1977-1999 period, the regional pattern of unemployment distress has undergone substantial shifts. It can be misleading to characterize changes in its spatial distribution between individual years since unemployment is highly cyclical and volatile. Thus we examine median rates of unemployment for our regional aggregates for different recession-to-recovery cyclical periods: 1977-1982, 1983-1991, and 1992-1999. These are documented in Table 3.

[Table 3 near here] 
In general, as the hypothetical center of the U.S. population has drifted South and West, so has concentrated unemployment distress. While the South and West have accounted for the majority of distressed regions over the entire period, their combined share is increasing. Over the period 1977 to 1982, the Midwest and Northeast accounted for roughly 36 percent of unemployment-distressed zones, a figure which fell to 28 percent over the period 1983 to 1991 and 22 percent from 1992 to 1999. The two regions accounted for just 10 percent of the population of U.S. unemployment-distressed zones from 1992 to 1999 compared to 39 percent over the period 1977-1982. Also, either the South or West has led all four regions in relative distress (the share of its own zones designated as distressed) in every year since 1980.

[Figure 6 near here]

These shifts undoubtedly reflect the differential regional impact of various national recessions, the maturation of the industrial economies of the West and South, and the growth of at-risk populations in the West (e.g., via immigration). The comparative severity of the mid1970s recession on the Northeast versus other Census regions is clearly evident in Figure 6. The figure also shows that the Midwest and Northeast made rapid and nearly complete recoveries from the early 1980s recession-at least in terms of unemployment distress-while the Midwest suffered only modestly from the 1992 recession. By contrast, the shares of distressed zones in the West and South regions have remained consistently higher over the 1990s.

\section{Income Distress up Significantly in 1990s}

Until the 1990s, the trendline of overall regional income distress in the contiguous U.S. remained notably flat. While the number of regions classified as distressed according to our threshold increased during the recessionary mid-1970s and early 1980s, most regions recovered quickly. For example, the share of U.S. regions classified as income-distressed rose to 30 
percent in 1975, fell to 20 percent in 1978, rose again to 26 percent in 1983 and fell to 21 percent in 1987. Median shares over the periods 1971-1975, 1976-1982, and 1983-1991 range from 22.9 to 24.4 percent (see Table 4).

Income distress in the 1990s, however, has been more severe and long-lasting. The share of income-distressed regions began rising significantly in 1991, peaked in 1996 at 37 percent, and had fallen to only 31 percent by 1998 . The median share of distressed regions over the 19921998 period was 35 percent nationally. The median incidence of distress by region ranged from 60 percent in the South to 13 percent in the Midwest over the 1992-1998 period. Figure 6 shows that the incidence has declined in all four Census regions since 1996, suggesting that the overall level of income distress may eventually return to pre-1991 levels. However, the substantially increased dependence of many regions on income maintenance programs, even if temporary, calls into question the distribution of benefits of the historic 1990s expansion. The difference in the persistence between income and unemployment distress matches how we generally understand those conditions of deprivation. Unemployment tends to be fleeting experience with individuals moving in and out of spells of unemployment over their lifetimes. A state of low income, or poverty, is much more pernicious and may be a lifetime condition. Finding a job for an unemployed individual is relatively simple to solve compared to building the skill base, employment history, and institutional climate necessary to raise individuals permanently out of poverty.

[Table 4 near here]

\section{Out-migration and Population Decline Problem Localized}

Regional population decline driven by rapid out-migration (as opposed to natural decrease) has declined significantly since the mid-1980s, when a combination of the farm crisis 
and contractions in the mining industry spurred substantial demographic shifts in the Great Plains and Mountain regions of the country. Over the period 1985-1991, the median annual share of zones in the lower 48 states designated as OPL-distressed by our threshold was 37 percent (see Table 5). Some 42 percent of the zones in the Midwest were OPL-distressed annually over this period, compared to 36 percent in the West, 32 percent in the South, and just 7 percent in the Northeast. The Great Plains fared worst by far: annually, roughly 73 percent of its zones posted high rates of out-migration in conjunction with population decline between 1985 and 1991 . By contrast, the median annual share of U.S. zones designated as OPL-distressed over the 1992-98 period was just 12 percent (with the share of the U.S. population that those zones represented less than 3 percent). The Plains saw its OPL-distress fall by half during this period, to 35 percent of its zones.

[Table 5 and Figure 7 near here]

What is unique about the Great Plains is that until the 1990s out-migration and population decline was accompanied by comparatively little sustained income or unemployment distress. This is clear in the top panel of Figure 7, which charts the dramatic increase in OPL-distress in the Plains in the mid- to late-1980s. Nearly 90 percent of Plains zones were OPL-distressed in 1986, the year of maximum unemployment distress for the region. But both OPL- and unemployment-distress fell rapidly thereafter, suggestive of an efficient adjustment process where the unemployed responded by migrating-not necessarily outside of Plains region but at least between commuter zones. The incidence of income-distress changed little until 1991, when it began climbing steadily. 
The concentration of OPL in the Plains vis-á-vis the rest of the contiguous U.S. is even clearer if we identify those zones designated strictly as OPL-distressed and neither income- nor unemployment-distressed. On average, only 8 percent of U.S. zones faced OPL distress in the absence of income or unemployment distress during the period 1992 to 1998, down from 24 percent over the 1985-1991 period (see Table 6). In 1998, there were 95 "OPL-only" zones across all four Census regions accounting for less than 1 percent of the population of the lower 48 states. Figure 8 shows that the majority of those zones (56 in total) were in the Plains, a pattern which has characterized every year of the series. Even then, such zones have generally constituted a small share of overall Plains population (averaging less than 10 percent since 1992). Those regions suffering from rapid out-migration and population decline in the absence of income or unemployment distress thus tend to be small agricultural communities of the nation's heartland, many of which may be in a process of long-term decline that ultimately began early in the $20^{\text {th }}$ century.

\section{[Table 7 near here]}

Table 7 reports the number of persistently distressed zones for all available years for each indicator and specifically for the 1988-1998 period (since the latter includes values for all three distress indicators). Thirty-seven percent of zones in the Midwest registered population decline for 7 or more years of the 11 year 1988-1998 period. Most of those zones are in the Plains, where 57 percent of zones declined for 7 or more years. Thirty-eight percent of Plains zones were persistently OPL-distressed, compared to a national average of 11 percent. The incidence of persistent unemployment distress was highest in the West (at 21 percent of Western zones) followed by the South (at 14 percent of the region's zones). Overall, income distress tends to be the most prolonged. Nationwide, one-third of all income-distressed zones between 1988 and 
1998 were so designated for 7 or more years. That figure rises to over half in the South and over two-thirds in the Delta. Forty percent of Appalachian zones were also persistently incomedistressed.

What we find, then, for the longest period for which we could obtain consistent data, is that most regions experiencing rapid out-migration in conjunction with population decline also posted high rates of unemployment or income distress that would make them eligible for development assistance in the hypothetical case. (It is hypothetical because we have not applied any agency's exact distress criteria.) Put differently, in any give year, most regions that are among the 25 percent most distressed in terms of OPL are also among the 25 percent most distressed in terms of income, unemployment, or both. The incidence of "OPL-only" distress might be even more circumscribed if we accounted for lead-lag effects; even with our short series, it appears unemployment rates may lead OPL, a fact that would be fully consistent with neoclassical adjustment models. If that were the case, it could be argued that measuring distress for OPL and unemployment in the same period results in an over-estimation of OPL distress in the latter periods of economic downturns. Here we ignore this problem for two reasons. First, few if any federal or state agencies consider lead-lag effects in distress measurement. Second, our migration series is too short to form any definitive conclusions about such effects.

Even while the OPL problem is limited in the context of the contiguous U.S. as a whole, it is nevertheless one that is highly localized to one U.S. region-the Great Plains. Thus, to the extent that rapid out-migration and population decline spur further economic decline rather than recovery, the Plains will suffer disproportionately at the hands of federal and state development programs that allocate resources based solely on other considerations (e.g., low income and unemployment). The following section considers the implications of these findings. 


\section{DISCUSSION}

We introduced this paper by arguing that a focus on out-migration and population decline by EDA or any other federal agency could be a moot point if few regions suffer from severe outmigration and depopulation in most periods, places with high out-migration and population loss are also typically identified by more conventional indicators, and those places with severe OPL but no unemployment or income distress are relatively evenly distributed geographically. ${ }^{4}$ These points are important because existing research on the beneficial effects of out-migration as a regional economic adjustment mechanism is not definitive. If out-migration does in fact lead to worsening economic conditions in some places, economic development programs allocated only on the basis of other kinds of distress are poorly targeted. At least if places with severe outmigration induced depopulation are few and more or less evenly distributed over space, the regional administrative process common to many federal government development programs may have compensating effects.

The case of the EDA, which delegates the disbursement of grant monies to its six regional offices, is instructive. While the EDA regions have long been authorized to consider out-migration and population decline in their allocation decisions, their own base funding levels have been determined traditionally by the geographic incidence of unemployment and, to a lesser extent, low income distress. Prior to fiscal year 1999, EDA headquarters annually applied a funding allocation formula that effectively "added-up" low income and unemployment distress by county (weighted by population) for each administrative region. Twenty-five percent of the year's Public Works allocation was allotted evenly across the six regions while 75 percent was distributed according to each region's share of total national distress as revealed by the formula. In 1998 the agency adopted a new Public Works allocation scheme that allocates 20 percent of 
funds equally across the regions, 40 percent on the basis of each region's share of total U.S. unemployed, and 40 percent on the basis of each region's share of the total U.S. poverty population. The new allocation formula includes a caveat that no region's percentage share of the total agency allocation can be adjusted downward by more than 10 percent from the previous year's allocation. Economic Adjustment program monies are allocated in a somewhat similar fashion, with unemployment, per capita income, and percentage change in total employment the key distress measures.

The fact that the EDA neglects out-migration concerns in its supra-regional allocation process is less significant if the incidence of OPL is more or less evenly distributed among its six regional jurisdictions. That is because each administrative region is open to consider outmigration and population loss in allocating its own base development funds. But if the OPL problem is concentrated in one or more of the six regions, those regions will be comparatively under-funded relative to the rest. Our findings suggest that while the problem is modest, this will nevertheless be the case. The Denver region, which encompasses several states where outmigration induced population decline is most common (North and South Dakota, Montana, Wyoming, Nebraska, Iowa and Kansas) is at the greatest disadvantage. In 1997, before the agency's internal review, the Seattle region was allocated the largest share of Public Works funds (at 24.0 percent), followed by Philadelphia (23.2 percent), Atlanta (18.8 percent), Austin (18.1 percent), Chicago (11 percent), and Denver (4.9 percent). A reorienting of priorities would essentially mean greater funding for Denver, in relative terms, and less for other EDA regions.

EDA's allocation scheme and aid qualification schedules are clearly a creature of intense political pressure on the agency to disburse federal resources widely even as it is charged with arresting economic decline in the most disadvantaged regions in the country. ${ }^{5}$ Thus it is perhaps 
a bit of a misnomer to describe the agency's funding practices as if they are based on a wellreasoned notion of distress and accompanying view of the regional development process. But at the same time, all development agencies' allocation schemes implicitly reflect a view of economic distress, whether intended or otherwise. And those schemes-assuming programs are efficacious-shape subsequent development patterns and ultimately the urban and regional spatial structure of the U.S. At the federal level, the current policy regime effectively ignores places facing out-migration induced population decline, presumably based on an argument that such communities have very limited economic prospects. But the government's implied position on adjustment is contradictory. Places suffering long-term population decline are assumed to be experiencing a "necessary" adjustment while communities that should arguably experience a downward adjustment of their own continue to draw resources. Few would argue that unemployment and low income are not important social concerns that demand policy attention. Since the cores of many of the nation's cities are the very places of persistent unemployment and poverty, current federal policies help to preserve the considerable human and physical investments in such places. However, until the evidence one way or another is more definitive, it is just as reasonable to postulate a limited economic future for communities with sustained unemployment or poverty as it is for places suffering significant out-migration induced population decline.

Of course, the crux of the matter is whether or not out-migration alleviates or induces economic distress. While the preponderance of theory and evidence argues for the former, a smaller body of research suggests reasonable scenarios supportive of the latter as well. ${ }^{6}$ Most scenarios suggest that the source of the distress is in the population adjustment process itself, a topic that has received comparatively little systematic attention in the literature even as studies of 
income convergence have proliferated (e.g. Barro and Sala-i-Martin 1990, Blanchard and Katz 1992, Carlino and Mills 1996, Rey and Montouri 1999). ${ }^{7}$

Popper and Popper $(1987,1994)$ argue that development in the Great Plains-and, by implication, many other rural areas-is environmentally unsustainable. Rural sociologists and planners counter that current rates of urbanization and associated urban diseconomies make continued expansion of many of the nation's metro areas environmentally unsustainable. For example, in a paper addressing the rural development problems of the Great Plains, Muehlbeier (1969, p. 1095) highlights an implication of the hands-off nature of regional development policy in the U.S.:

The largely unplanned economic development of this nation, in which population and industry were permitted to concentrate in a relatively few large cities, has taken its toll. Those in the cities have such problems as congestion and pollution. The public bears the cost of such problems as urban renewal. The Plains has the problems associated with a declining population. To date, little has been done to assure that economic growth will take place where it is the most economic, taking into account both industry and public costs.

Whoever is right, a legitimate debate about development policy goals that admits that federal policies have real implications for population settlement patterns is overdue. ${ }^{8}$ EDA's recent focus on depopulating communities may help to stimulate such a debate, regardless of its motives and even if the agency has not altered its unemployment and income based funding scheme in any fundamental way. For their part, researchers would advance the debate by devoting more attention to the process of adjustment rather than assuming it away as instantaneous. 


\section{NOTES}

1. Excluding 1987, for which data are not available.

2. It is important to note that we are not tallying the total number of distressed persons, e.g., total unemployed in each region, but rather the population of zones designated as distressed based on the unemployment rate threshold. The latter is an important indicator since most economic development resource allocation schemes take into account the population size of eligible distressed regions.

3. Maps for the three distress indicators for every period in each indicator's respective series can be viewed at http://www.geog.ucsb.edu/ sweeney/research/distress.htm.

4. The expected lag in out-migration vis-á-vis unemployment and income distress often cannot be observed with the annual series available to most agencies.

5. We thank an anonymous reviewer for making this point.

6. Numerous descriptive studies chart in-migration, out-migration, birth, and death trends by county or state, with specific attention to places with high rates of natural decrease and general aging of the population (examples are Beale 1969, 1974 and Chang 1974). Many such studies are focused on farming and were conducted two to three decades ago (e.g., Hein 1960, Lowenthal and Comitas 1962, Bollinger 1972, Fuguitt 1971, Whiting 1974, Alonso and Rust 1975). Since the farm population in the United States peaked in 1930, many rural agricultural communities in the U.S. have been in decline for nearly seventy years (save, for some, a brief resurgence in the 1970s). Goldthwait's seminal article "A town that has gone downhill," published in 1927, is still an important reference for the types of distress characteristic of gradually depopulating communities (e.g., see Baltensperger 1991). 
7. An important exception is work by Vanderkamp $(1970,1987,1989)$.

8. The link between federal economic development efforts and population settlement patterns received much more attention in the 1960s and 1970s than it does today (e.g., see Commission on Population Growth and the American Future, 1972, and the extensive set of research reports included therein). 


\section{BIBLIOGRAPHY}

Alonso, William, and Edgar Rust. 1975. Life in the Economically Declining Parts of Montana, North Dakota and Wyoming. Berkeley, CA: Berkeley Planning Associates.

Baltensperger, B. H. 1991. A county that has gone downhill. Geographical Review 81: 433-42.

Barro, R. J., and X. Sala-I-Martin. 1990. Convergence across states and regions. Brookings Papers on Economic Activity 1: 107-82.

Beale, C. L. 1969. Natural decrease of population: The current and prospective status of an emergent American phenomenon. Demography 6: 91-99.

Beale, C. L. 1974. Quantitative dimensions of decline and stability among rural communities. In Communities Left Behind: Alternatives for Development, edited by L. R. Whiting, 3-21. Ames: Iowa State University Press.

Bernstein, J., E. C. McNichol, L. Mishel, and R. Zahradnik. 2000. Pulling Apart: A State-byState Analysis of Income Trends. Washington, DC: Economic Policy Institute, Center on Budget and Policy Priorities.

Blanchard, O. J., and L. F. Katz. 1992. Regional evolutions. Brookings Papers on Economic Activity 1: 1-75.

Bollinger, W. L. 1972. The economic and social impact of the depopulation process upon four selected counties in Idaho. In Commission on Population Growth and the American Future, Research Reports, Volume 5, Population Distribution and Policy, edited by S. M. Mazie, 561-96. Washington, DC: U.S. Government Printing Office.

Borts, G., and J. Stein. 1964. Economic Growth in a Free Market. New York: Columbia University Press. 
Bronars, Stephen and Stephen Trejo. 1992. Self-Selection and Internal Migration in the United States. Journal of Urban Economics 32: 159-185.

Carlino, G. A., and L. Mills. 1996. Testing neoclassical convergence in regional incomes and earnings. Regional Science and Urban Economics 26: 565-90.

Chang, H. C. 1974. Natural population decrease in Iowa counties. Demography 11: 657-72.

Clark, G. L., M. S. Gertler, and J. E. M. Whiteman. 1986. Regional Dynamics: Studies in Adjustment Theory. Boston: Allen and Unwin.

Commission on Population Growth and the American Future. 1972. Population and the American Future. Volumes 1 and 2. Washington, DC: U. S. Government Printing Office.

Feser, E. J., and S. H. Sweeney. 1998. Out-migration, Population Decline, and Regional Economic Distress. Washington, DC: U.S. Economic Development Administration.

Fuguitt, G. V. 1971. The places left behind: Population trends and policy for rural America. Rural Sociology 36: 449-70.

Fullenbaum, R. F., and M. A. McNeill. 1995. Survey and Comparison of Distressed Area Definitions. Washington, DC: Appalachian Regional Commission.

Glasmeier, A. K., and K. G. Fuellhart. 1999. Building on past experience: Creating a new future for distressed counties. Unpublished manuscript.

Goldthwait, J. W. 1927. Town that has gone downhill. Geographical Review 17: 527-52.

Hein, C. J. 1960. Rural local government in sparsely populated areas. Journal of Farm Economics 42: 827-41.

Isserman, A. M., Plane, D. A., and D. McMillan. 1982. Internal migration in the United States: A review of federal data. Review of Public Data Use 10: 285-311. 
Kwok, V. and H. Leland. 1982. An economic model of the brain drain. American Economic Review 72: 91-100.

Lowenthal, D. and L. Comitas. 1962. Emigration and depopulation: Some neglected aspects of population geography. Geographical Review 3: 195-210.

McCombie, J. 1988a. A synoptic view of regional growth and unemployment: I - The neoclassical theory. Urban Studies 25: 267-81.

McCombie, J. 1988b. A synoptic view of regional growth and unemployment: II - The post-Keynesian theory. Urban Studies 25: 399-417.

Muehlbeier, J. 1969. Problems that persist in the Great Plains. American Journal of Agricultural Economics 51: 1089-96.

Myrdal, G. 1957. Economic Theory and Underdeveloped Regions. New York: Harper and Row.

Popper, D. E., and F. J. Popper. 1987. The Great Plains from dust to dust. Planning, pp. 12-18 (December).

Popper, F. J., and D. E Popper. 1994. Great Plains: Checkered past, hopeful future. Forum for Applied Research and Public Policy 9: 89-100 (Winter).

Rey, S., and B. Montouri. 1999. US regional income convergence: A spatial econometric perspective. Regional Studies 33: 143-56.

Sen, A. 1999. Development as Freedom. New York: Alfred A. Knopf.

Sjaastad, L. 1962. The costs and returns of human migration. Journal of Political Economy 70: 80-93.

Vanderkamp, J. 1970. The effect of out-migration on regional employment. Canadian Journal of Economics 3: 541-9. 
Vanderkamp, J. 1987. Regional disparities: A model with some econometric results for Canada. In Regional Economic Development, edited by B. Higgins and D. J. Savoie, 269-96. Boston: Unwin Hyman.

Vanderkamp, J. 1989. The role of migration in regional adjustment. In Migration and Labor Market Adjustment, edited by J. van Dijk, H. Folmer, H. W. Herzog, and A. M. Schlottmann, 147-75. Dordrecht: Kluwer.

Whiting, Larry R. 1974. Communities Left Behind: Alternatives for Development. Ames: Iowa State University Press.

Wood, L. E., and G. A. Bischak. 1999. Progress and Challenges in Reducing Economic Distress in Appalachia: An Analysis of National and Regional Trends Since 1960. Washington, DC: Appalachian Regional Commission. 
Table 1

Commuter zones by major region, contiguous U.S.

\begin{tabular}{|c|c|c|c|c|c|c|c|c|}
\hline & \multirow[b]{2}{*}{ Contiguous U.S. } & \multicolumn{4}{|c|}{ Census Regions } & \multirow[b]{2}{*}{ Plains } & \multirow[b]{2}{*}{ Delta } & \multirow[b]{2}{*}{ ARC } \\
\hline & & Mwest & Neast & South & West & & & \\
\hline Commuter zones & 722 & 251 & 43 & 290 & 138 & 160 & 58 & 105 \\
\hline Pct share of U.S. zones & 100.0 & 34.8 & 6.0 & 40.2 & 19.1 & 22.2 & 8.0 & 14.5 \\
\hline 1969 population (000s) & 199,794 & 56,308 & 48,612 & 62,043 & 32,831 & 9,451 & 11,147 & 31,360 \\
\hline 1998 population (000s) & 268,399 & 63,227 & 51,723 & 95,203 & 58,246 & 12,869 & 13,302 & 38,916 \\
\hline Percent change, '69-'98 & 34.3 & 12.3 & 6.4 & 53.4 & 77.4 & 36.2 & 19.3 & 24.1 \\
\hline Pct share of U.S. population, '69 & 100.0 & 28.2 & 24.3 & 31.1 & 16.4 & 4.7 & 5.6 & 15.7 \\
\hline Pct share of U.S. population, '98 & 100.0 & 23.4 & 19.2 & 35.3 & 22.2 & 4.8 & 4.9 & 14.4 \\
\hline
\end{tabular}

Population data are from Bureau of Economic Analysis. 
Table 2

\section{Regional economic distress at the end of 1990s}

\begin{tabular}{|c|c|c|c|c|c|c|c|c|}
\hline \multirow[b]{2}{*}{ Indicator } & \multirow[b]{2}{*}{ U.S. } & \multicolumn{4}{|c|}{ Census Regions } & \multirow[b]{2}{*}{ Plains } & \multirow[b]{2}{*}{ Delta } & \multirow[b]{2}{*}{ ARC } \\
\hline & & Mwest & Neast & South & West & & & \\
\hline \multicolumn{9}{|c|}{ Number of distressed zones in each area } \\
\hline Unemployment ('99) & 52 & 2 & 2 & 27 & 21 & 4 & 7 & 8 \\
\hline Income ('98) & 224 & 23 & 8 & 150 & 43 & 39 & 38 & 42 \\
\hline OPL ('98) & 157 & 77 & 13 & 31 & 36 & 80 & 8 & 11 \\
\hline \multicolumn{9}{|c|}{ Percent of zones designated distressed in each area } \\
\hline Unemployment ('99) & 7.2 & 0.8 & 4.7 & 9.3 & 15.2 & 2.5 & 12.1 & 7.6 \\
\hline Income ('98) & 31.1 & 9.2 & 18.6 & 55.1 & 27.9 & 24.5 & 65.5 & 42.9 \\
\hline OPL ('98) & 21.4 & 30.7 & 30.2 & 10.7 & 23.8 & 50.6 & 13.8 & 10.5 \\
\hline \multicolumn{9}{|c|}{ Percent share of all U.S. distressed zones } \\
\hline Unemployment ('99) & $\mathrm{n} / \mathrm{a}$ & 3.8 & 3.8 & 51.9 & 40.4 & 7.7 & 13.5 & 15.4 \\
\hline Income ('98) & $\mathrm{n} / \mathrm{a}$ & 10.3 & 3.6 & 67.0 & 19.2 & 17.4 & 17.0 & 18.8 \\
\hline OPL ('98) & $\mathrm{n} / \mathrm{a}$ & 49.0 & 8.3 & 19.7 & 22.9 & 51.0 & 5.1 & 7.0 \\
\hline \multicolumn{9}{|c|}{ Percent of population in each area in distressed zones } \\
\hline Unemployment ('99) & 3.4 & 0.2 & 0.6 & 3.9 & 8.6 & 1.7 & 5.7 & 1.2 \\
\hline Income ('98) & 22.4 & 2.8 & 27.5 & 21.2 & 41.0 & 8.6 & 42.7 & 12.9 \\
\hline OPL ('98) & 4.9 & 5.1 & 9.9 & 3.8 & 1.9 & 17.0 & 5.0 & 6.5 \\
\hline \multicolumn{9}{|c|}{ Percent share of U.S. population in distressed zones } \\
\hline Unemployment ('99) & $\mathrm{n} / \mathrm{a}$ & 1.3 & 3.1 & 40.7 & 54.8 & 2.4 & 8.3 & 5.2 \\
\hline Income ('98) & $\mathrm{n} / \mathrm{a}$ & 2.9 & 23.7 & 33.5 & 39.8 & 1.8 & 9.5 & 8.4 \\
\hline OPL ('98) & $\mathrm{n} / \mathrm{a}$ & 24.6 & 39.7 & 27.5 & 8.2 & 16.7 & 5.1 & 19.6 \\
\hline
\end{tabular}

See text for definitions and sources. 
Table 3

\section{Regional distribution of unemployment distress}

Figures are medians over respective periods

\begin{tabular}{|c|c|c|c|c|c|c|c|c|}
\hline \multirow[b]{2}{*}{ Period } & \multirow[b]{2}{*}{ U.S. } & \multicolumn{4}{|c|}{ Census Regions } & \multirow[b]{2}{*}{ Plains } & \multirow[b]{2}{*}{ Delta } & \multirow[b]{2}{*}{ ARC } \\
\hline & & Mwest & Neast & South & West & & & \\
\hline \multicolumn{9}{|c|}{ Percent of zones designated distressed in each area } \\
\hline '77 to ' 82 & 24.0 & 19.5 & 34.9 & 22.2 & 29.2 & 2.8 & 37.9 & 37.1 \\
\hline '83 to '91 & 33.5 & 21.9 & 29.1 & 38.9 & 35.2 & 5.6 & 68.1 & 52.4 \\
\hline '92 to '99 & 15.1 & 6.4 & 7.0 & 16.2 & 22.5 & 3.8 & 22.4 & 15.2 \\
\hline \multicolumn{9}{|c|}{ Percent share of U.S. unemployment-distressed zones } \\
\hline '77 to ' 82 & $\mathrm{n} / \mathrm{a}$ & 26.8 & 9.3 & 37.3 & 24.3 & 2.9 & 13.3 & 22.2 \\
\hline '83 to '91 & $\mathrm{n} / \mathrm{a}$ & 24.4 & 4.0 & 46.8 & 23.7 & 5.0 & 16.1 & 21.3 \\
\hline '92 to '99 & $\mathrm{n} / \mathrm{a}$ & 15.4 & 3.6 & 47.5 & 38.0 & 6.9 & 13.7 & 15.2 \\
\hline \multicolumn{9}{|c|}{ Percent of population in each area in distressed zones } \\
\hline '77 to ' 82 & 22.3 & 20.0 & 8.6 & 14.5 & 22.3 & 2.3 & 19.3 & 24.2 \\
\hline '83 to '91 & 20.2 & 20.5 & 11.5 & 23.1 & 14.4 & 2.8 & 54.7 & 28.6 \\
\hline '92 to '99 & 5.3 & 1.8 & 0.7 & 6.5 & 11.7 & 1.7 & 8.5 & 4.4 \\
\hline \multicolumn{9}{|c|}{ Percent share of U.S. population in unemployment-distressed zones } \\
\hline '77 to '82 & $\mathrm{n} / \mathrm{a}$ & 21.8 & 16.7 & 30.6 & 21.4 & 0.5 & 7.5 & 23.2 \\
\hline '83 to '91 & $\mathrm{n} / \mathrm{a}$ & 25.1 & 9.7 & 43.7 & 19.1 & 0.7 & 13.8 & 20.6 \\
\hline '92 to '99 & $\mathrm{n} / \mathrm{a}$ & 7.2 & 3.1 & 40.7 & 47.6 & 1.0 & 5.8 & 10.8 \\
\hline
\end{tabular}

See text for definitions and sources. 
Table 4

Regional distribution of income distress

Figures are medians over respective periods

\begin{tabular}{|c|c|c|c|c|c|c|c|c|}
\hline \multirow[b]{2}{*}{ Period } & \multirow[b]{2}{*}{ U.S. } & \multicolumn{4}{|c|}{ Census Regions } & \multirow[b]{2}{*}{ Plains } & \multirow[b]{2}{*}{ Delta } & \multirow[b]{2}{*}{ ARC } \\
\hline & & Mwest & Neast & South & West & & & \\
\hline \multicolumn{9}{|c|}{ Percent of zones designated distressed in each area } \\
\hline '69 to '70 & 18.6 & 4.6 & 2.3 & 33.6 & 17.9 & 9.6 & 49.1 & 26.9 \\
\hline '71 to '75 & 22.9 & 6.1 & 12.1 & 41.2 & 19.0 & 9.1 & 60.0 & 34.1 \\
\hline '76 to ' 82 & 24.4 & 10.3 & 22.6 & 42.7 & 14.2 & 8.3 & 57.1 & 39.8 \\
\hline '83 to '91 & 23.3 & 13.1 & 14.2 & 37.5 & 17.3 & 8.8 & 50.2 & 35.8 \\
\hline '92 to '98 & 34.9 & 12.5 & 30.6 & 59.9 & 28.7 & 23.5 & 70.7 & 52.8 \\
\hline \multicolumn{9}{|c|}{ Percent share of U.S. income-distressed zones } \\
\hline ' 69 to ' 70 & $\mathrm{n} / \mathrm{a}$ & 8.7 & 0.7 & 74.9 & 15.6 & 8.9 & 24.9 & 22.5 \\
\hline '71 to '75 & $\mathrm{n} / \mathrm{a}$ & 9.2 & 3.1 & 72.8 & 15.0 & 7.3 & 24.1 & 22.4 \\
\hline '76 to ' 82 & $\mathrm{n} / \mathrm{a}$ & 14.8 & 5.8 & 68.2 & 11.2 & 7.0 & 19.9 & 23.4 \\
\hline '83 to '91 & $\mathrm{n} / \mathrm{a}$ & 19.7 & 3.6 & 60.9 & 15.7 & 8.1 & 17.7 & 21.3 \\
\hline '92 to '98 & $\mathrm{n} / \mathrm{a}$ & 12.5 & 5.2 & 64.7 & 17.6 & 14.9 & 16.4 & 20.6 \\
\hline \multicolumn{9}{|c|}{ Percent of population in each area in distressed zones } \\
\hline '69 to '70 & 8.9 & 0.8 & 11.7 & 12.6 & 11.7 & 3.5 & 26.8 & 7.0 \\
\hline '71 to '75 & 19.0 & 3.3 & 28.7 & 16.7 & 35.6 & 3.9 & 34.4 & 10.2 \\
\hline '76 to ' 82 & 19.6 & 8.3 & 37.0 & 17.2 & 19.5 & 3.3 & 34.6 & 13.3 \\
\hline '83 to '91 & 12.4 & 8.1 & 12.1 & 13.5 & 15.7 & 3.4 & 26.6 & 11.5 \\
\hline '92 to '98 & 25.8 & 4.6 & 32.1 & 25.9 & 43.3 & 8.9 & 56.3 & 23.0 \\
\hline \multicolumn{9}{|c|}{ Percent share of U.S. population in income-distressed zones } \\
\hline '69 to '70 & $\mathrm{n} / \mathrm{a}$ & 2.9 & 22.0 & 49.3 & 25.7 & 2.0 & 19.1 & 13.9 \\
\hline '71 to '75 & $\mathrm{n} / \mathrm{a}$ & 3.8 & 36.1 & 28.6 & 31.5 & 1.0 & 10.4 & 8.4 \\
\hline '76 to ' 82 & $\mathrm{n} / \mathrm{a}$ & 10.9 & 42.5 & 29.9 & 16.7 & 0.8 & 9.9 & 10.6 \\
\hline '83 to '91 & $\mathrm{n} / \mathrm{a}$ & 16.1 & 15.8 & 41.7 & 26.3 & 1.5 & 12.8 & 15.3 \\
\hline '92 to '98 & $\mathrm{n} / \mathrm{a}$ & 4.2 & 24.6 & 35.3 & 35.9 & 1.7 & 10.9 & 12.8 \\
\hline
\end{tabular}

See text for definitions and sources. 
Table 5

Regional distribution of OPL distress

Figures are medians over respective periods

\begin{tabular}{|c|c|c|c|c|c|c|c|c|}
\hline \multirow[b]{2}{*}{ Period } & \multirow[b]{2}{*}{ U.S. } & \multicolumn{4}{|c|}{ Census Regions } & \multirow[b]{2}{*}{ Plains } & \multirow[b]{2}{*}{ Delta } & \multirow[b]{2}{*}{ ARC } \\
\hline & & Mwest & Neast & South & West & & & \\
\hline \multicolumn{9}{|c|}{ Percent of zones designated distressed in each area } \\
\hline '85 to '91 & 37.3 & 41.6 & 7.0 & 32.1 & 36.2 & 72.5 & 39.7 & 22.9 \\
\hline '92 to '98 & 11.8 & 17.9 & 14.0 & 9.7 & 9.8 & 35.0 & 12.1 & 3.8 \\
\hline \multicolumn{9}{|c|}{ Percent share of U.S. OPL-distressed zones } \\
\hline '85 to '91 & $\mathrm{n} / \mathrm{a}$ & 45.1 & 1.2 & 34.6 & 19.8 & 42.5 & 8.4 & 9.1 \\
\hline '92 to '98 & $\mathrm{n} / \mathrm{a}$ & 51.9 & 5.9 & 25.8 & 14.7 & 55.8 & 6.4 & 5.2 \\
\hline \multicolumn{9}{|c|}{ Percent of population in each area in distressed zones } \\
\hline '85 to '91 & 10.8 & 9.8 & 2.4 & 11.6 & 5.3 & 34.9 & 25.0 & 9.6 \\
\hline '92 to '98 & 2.2 & 2.6 & 4.1 & 2.1 & 0.3 & 9.2 & 4.3 & 4.3 \\
\hline \multicolumn{9}{|c|}{ Percent share of U.S. population in OPL-distressed zones } \\
\hline '85 to '91 & $\mathrm{n} / \mathrm{a}$ & 26.5 & 10.5 & 51.7 & 9.0 & 21.9 & 15.3 & 17.8 \\
\hline '92 to '98 & $\mathrm{n} / \mathrm{a}$ & 28.8 & 35.5 & 33.6 & 3.9 & 20.6 & 9.8 & 19.6 \\
\hline
\end{tabular}

See text for definitions and sources. 
Table 6

\section{OPL distress only}

OPL zones without unemployment or income distress

Figures are medians over respective periods

\begin{tabular}{|c|c|c|c|c|c|c|c|c|}
\hline \multirow[b]{2}{*}{ Period } & \multirow[b]{2}{*}{ U.S. } & \multicolumn{4}{|c|}{ Census Regions } & \multirow[b]{2}{*}{ Plains } & \multirow[b]{2}{*}{ Delta } & \multirow[b]{2}{*}{$\mathrm{ARC}$} \\
\hline & & Mwest & Neast & South & West & & & \\
\hline \multicolumn{9}{|c|}{ Percent of distressed zones in each area } \\
\hline '85 to '91 & 23.8 & 38.3 & 1.2 & 12.3 & 22.3 & 68.9 & 1.8 & 1.0 \\
\hline '92 to '98 & 7.9 & 16.5 & 0.0 & 2.2 & 6.0 & 29.1 & 1.8 & 0.0 \\
\hline \multicolumn{9}{|c|}{ Percent share of U.S. OPL (only)-distressed zones } \\
\hline '85 to '91 & $\mathrm{n} / \mathrm{a}$ & 56.9 & 0.3 & 23.6 & 19.3 & 64.3 & 0.8 & 0.6 \\
\hline '92 to '98 & $\mathrm{n} / \mathrm{a}$ & 70.5 & 0.0 & 12.2 & 14.5 & 73.2 & 1.1 & 0.0 \\
\hline \multicolumn{9}{|c|}{ Percent of population in each area in distressed zones } \\
\hline ' 85 to '91 & 3.9 & 7.0 & 0.6 & 4.3 & 1.8 & 30.7 & 1.3 & 2.1 \\
\hline '92 to '98 & 0.9 & 2.2 & 0.0 & 1.1 & 0.2 & 7.9 & 0.0 & 0.0 \\
\hline \multicolumn{9}{|c|}{ Percent share of U.S. population in OPL (only)-distressed zones } \\
\hline ' 85 to ' 91 & $\mathrm{n} / \mathrm{a}$ & 44.6 & 3.3 & 33.9 & 10.6 & 39.3 & 1.9 & 7.9 \\
\hline '92 to '98 & $\mathrm{n} / \mathrm{a}$ & 54.1 & 0.0 & 35.3 & 5.2 & 29.6 & 0.6 & 0.0 \\
\hline
\end{tabular}

See text for definitions and sources. 
Table 7

Regions of persistent distress

(Share of each region's total commuting zones in parentheses)

\begin{tabular}{|c|c|c|c|c|c|c|c|c|}
\hline \multirow[t]{3}{*}{ Region } & \multicolumn{2}{|c|}{ Population decline } & \multicolumn{2}{|c|}{ OPL } & \multicolumn{2}{|c|}{ Unemployment } & \multicolumn{2}{|c|}{ Low income } \\
\hline & \multicolumn{2}{|c|}{$1970-98$} & \multicolumn{2}{|c|}{$1985-98$} & \multicolumn{2}{|c|}{$1977-99$} & \multicolumn{2}{|c|}{$1969-98$} \\
\hline & 127 & $(18 \%)$ & 100 & $(14 \%)$ & 81 & $(11 \%)$ & 137 & $(19 \%)$ \\
\hline Midwest & 85 & $(34 \%)$ & 55 & $(22 \%)$ & 15 & $(6 \%)$ & 16 & $(7 \%)$ \\
\hline Northeast & 7 & $(16 \%)$ & 0 & $(0 \%)$ & 3 & $(7 \%)$ & 6 & $(14 \%)$ \\
\hline South & 24 & $(8 \%)$ & 29 & $(10 \%)$ & 34 & $(12 \%)$ & 97 & $(34 \%)$ \\
\hline West & 11 & $(8 \%)$ & 16 & $(12 \%)$ & 29 & $(21 \%)$ & 18 & $(14 \%)$ \\
\hline Plains & 71 & $(44 \%)$ & 71 & $(45 \%)$ & 3 & $(2 \%)$ & 10 & $(7 \%)$ \\
\hline Delta & 9 & $(16 \%)$ & 6 & $(10 \%)$ & 13 & $(23 \%)$ & 30 & $(52 \%)$ \\
\hline \multirow[t]{2}{*}{ ARC } & 7 & $(7 \%)$ & 3 & $(3 \%)$ & 15 & $(14 \%)$ & 34 & $(32 \%)$ \\
\hline & \multicolumn{2}{|c|}{$1988-98$} & \multicolumn{2}{|c|}{$1988-98$} & \multicolumn{2}{|c|}{$1988-98$} & \multicolumn{2}{|c|}{$1988-98$} \\
\hline U.S. & 168 & $(23 \%)$ & 81 & $(11 \%)$ & 87 & $(12 \%)$ & 221 & $(31 \%)$ \\
\hline Midwest & 93 & $(37 \%)$ & 43 & $(17 \%)$ & 15 & $(6 \%)$ & 30 & $(12 \%)$ \\
\hline Northeast & 7 & $(16 \%)$ & 1 & $(2 \%)$ & 3 & $(7 \%)$ & 9 & $(21 \%)$ \\
\hline South & 49 & $(17 \%)$ & 25 & $(9 \%)$ & 40 & $(14 \%)$ & 145 & $(51 \%)$ \\
\hline West & 19 & $(14 \%)$ & 12 & $(9 \%)$ & 29 & $(21 \%)$ & 37 & $(27 \%)$ \\
\hline Plains & 91 & $(57 \%)$ & 61 & $(38 \%)$ & 4 & $(3 \%)$ & 28 & $(18 \%)$ \\
\hline Delta & 15 & $(26 \%)$ & 5 & $(9 \%)$ & 15 & $(26 \%)$ & 38 & $(68 \%)$ \\
\hline ARC & 12 & $(11 \%)$ & 1 & $(1 \%)$ & 17 & $(16 \%)$ & 42 & $(40 \%)$ \\
\hline
\end{tabular}

Source: Authors' calculations with BLS, IRS, and BEA data. 


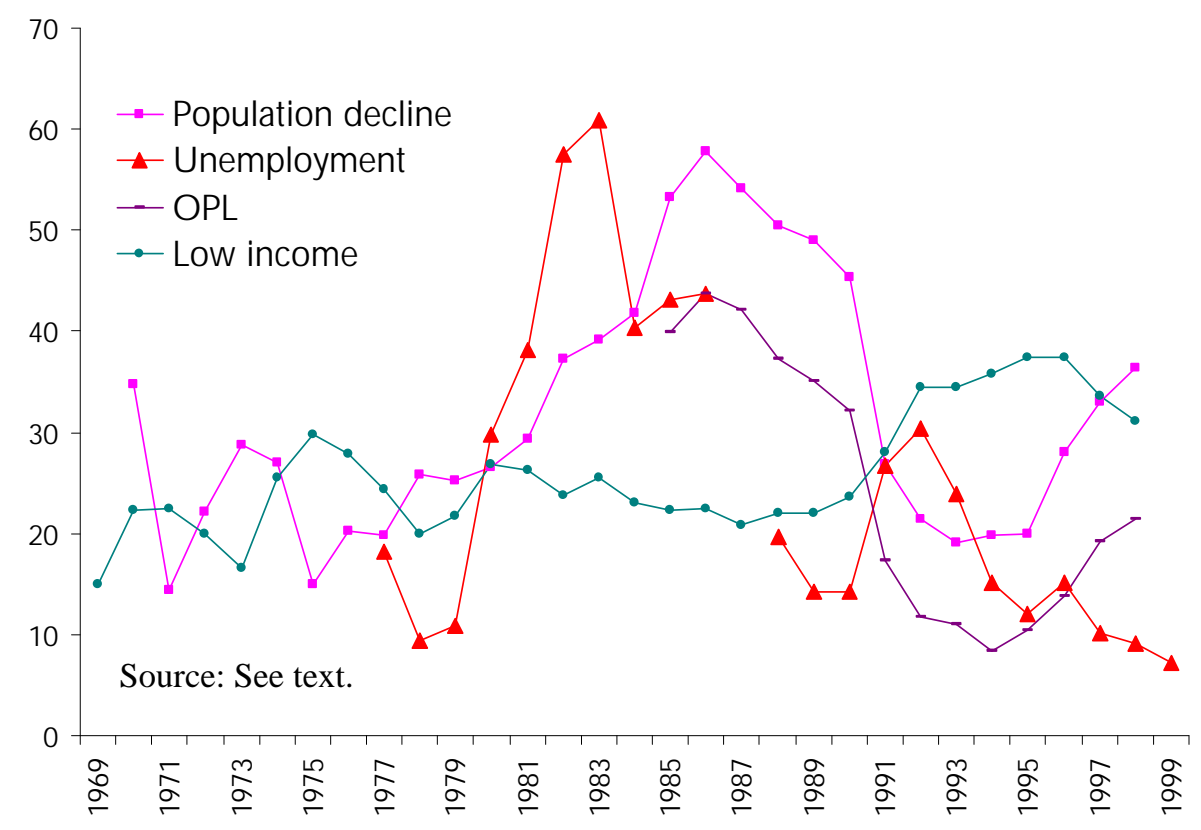

Figure. 1

Share of contiguous U.S. regions distressed in each period 


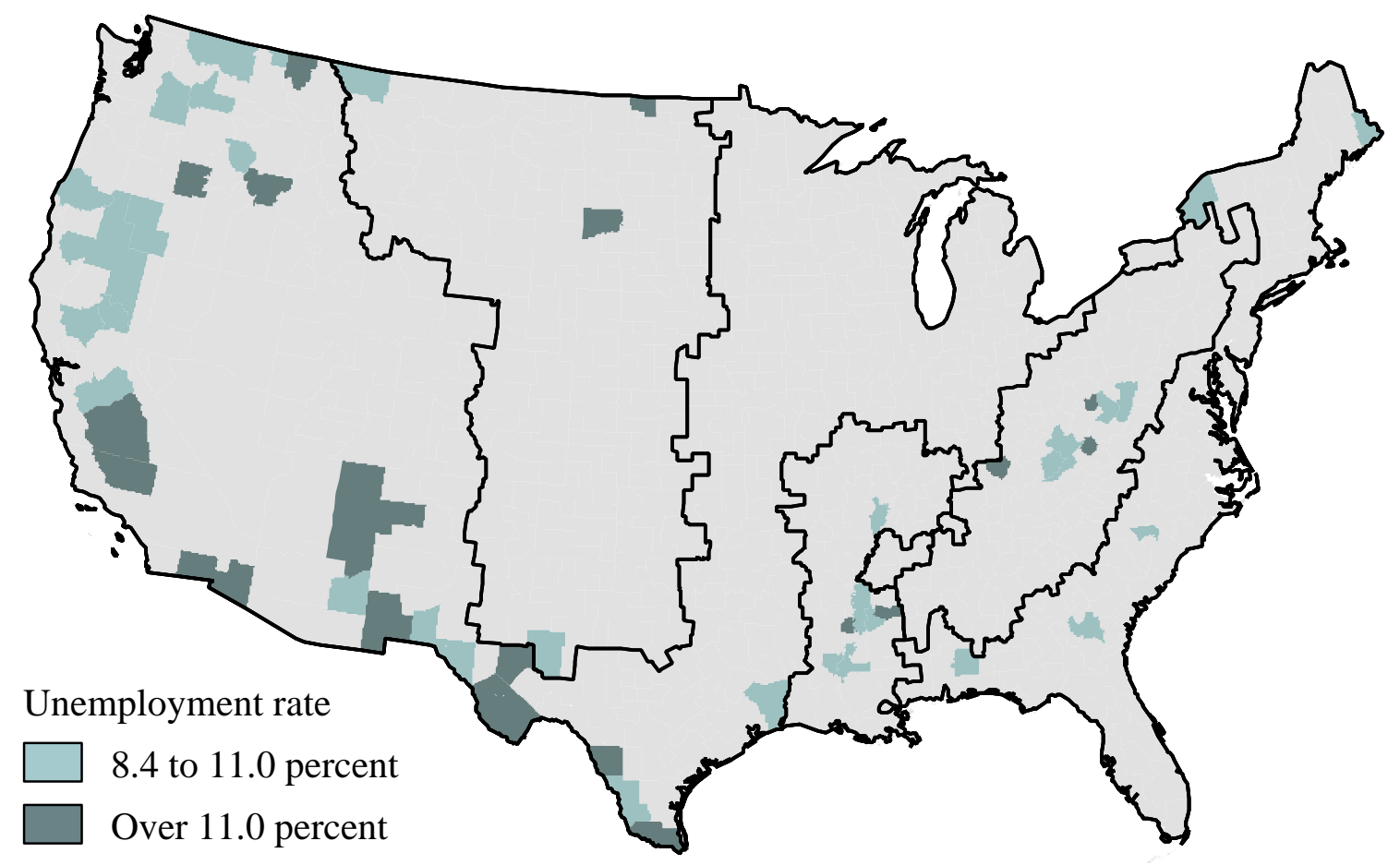

Figure 2. Regional unemployment distress, 1999 


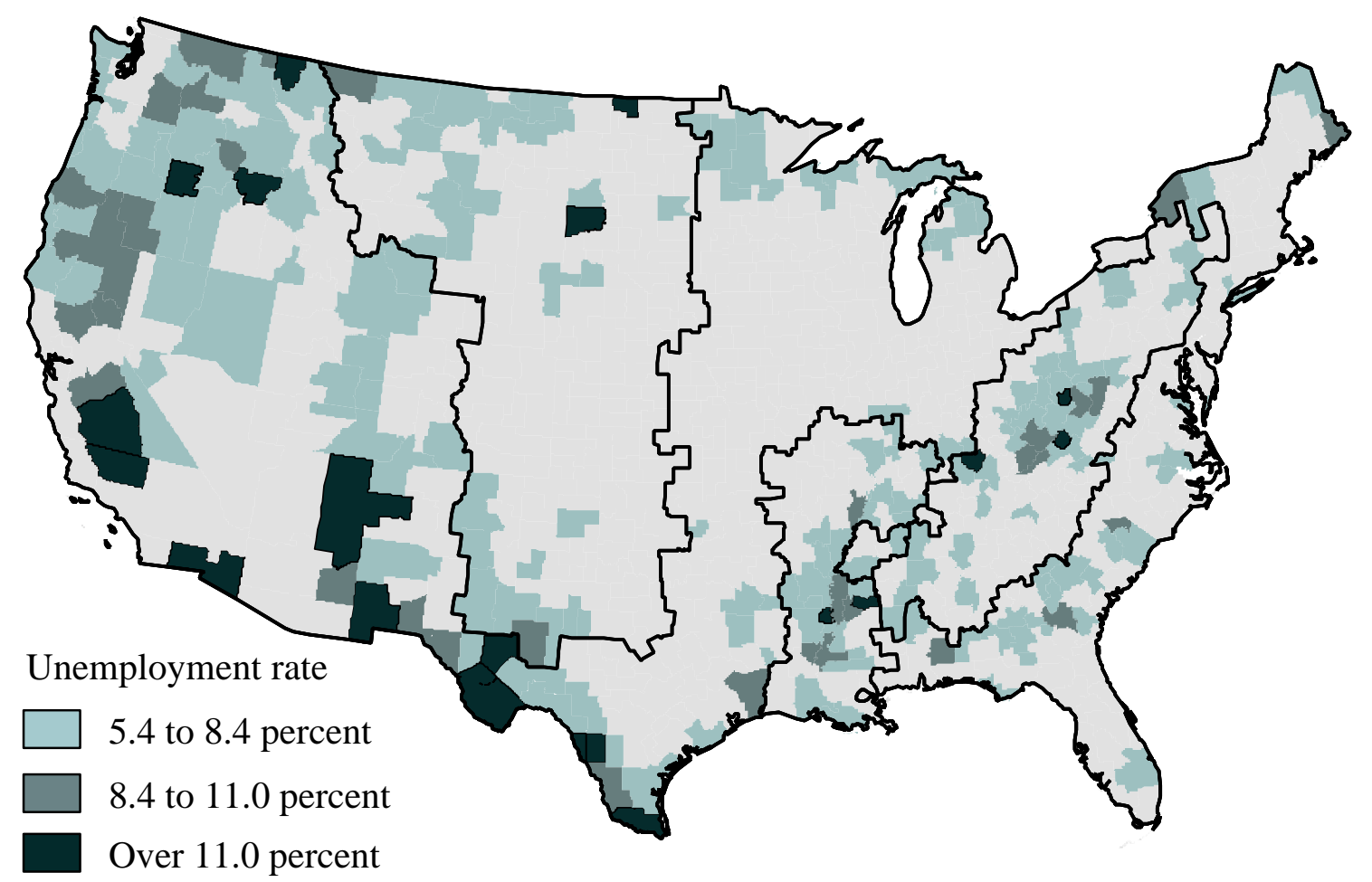

Figure 3. Regional unemployment distress, EDA threshold, 1999 


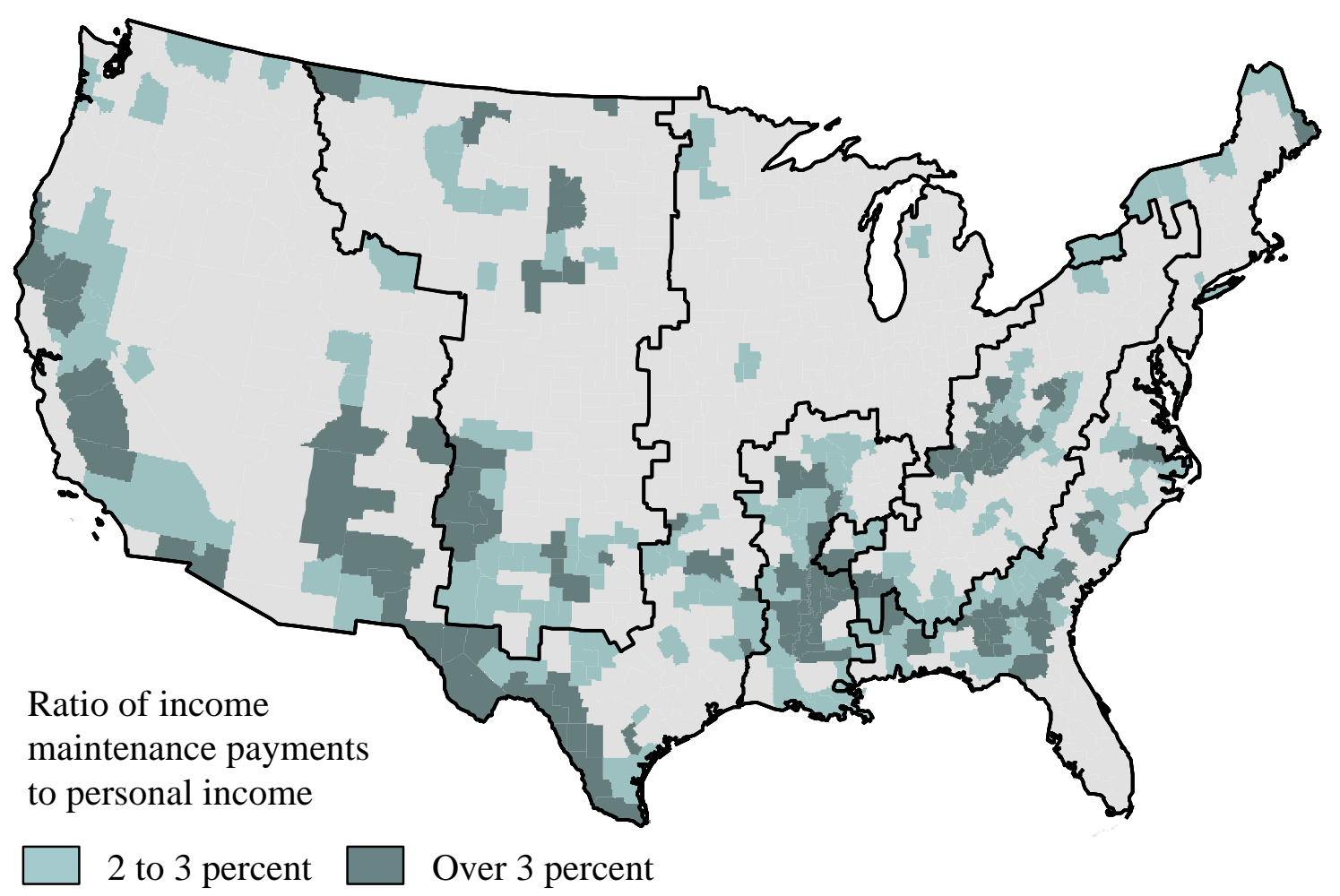

Figure 4. Regional income distress, 1998 


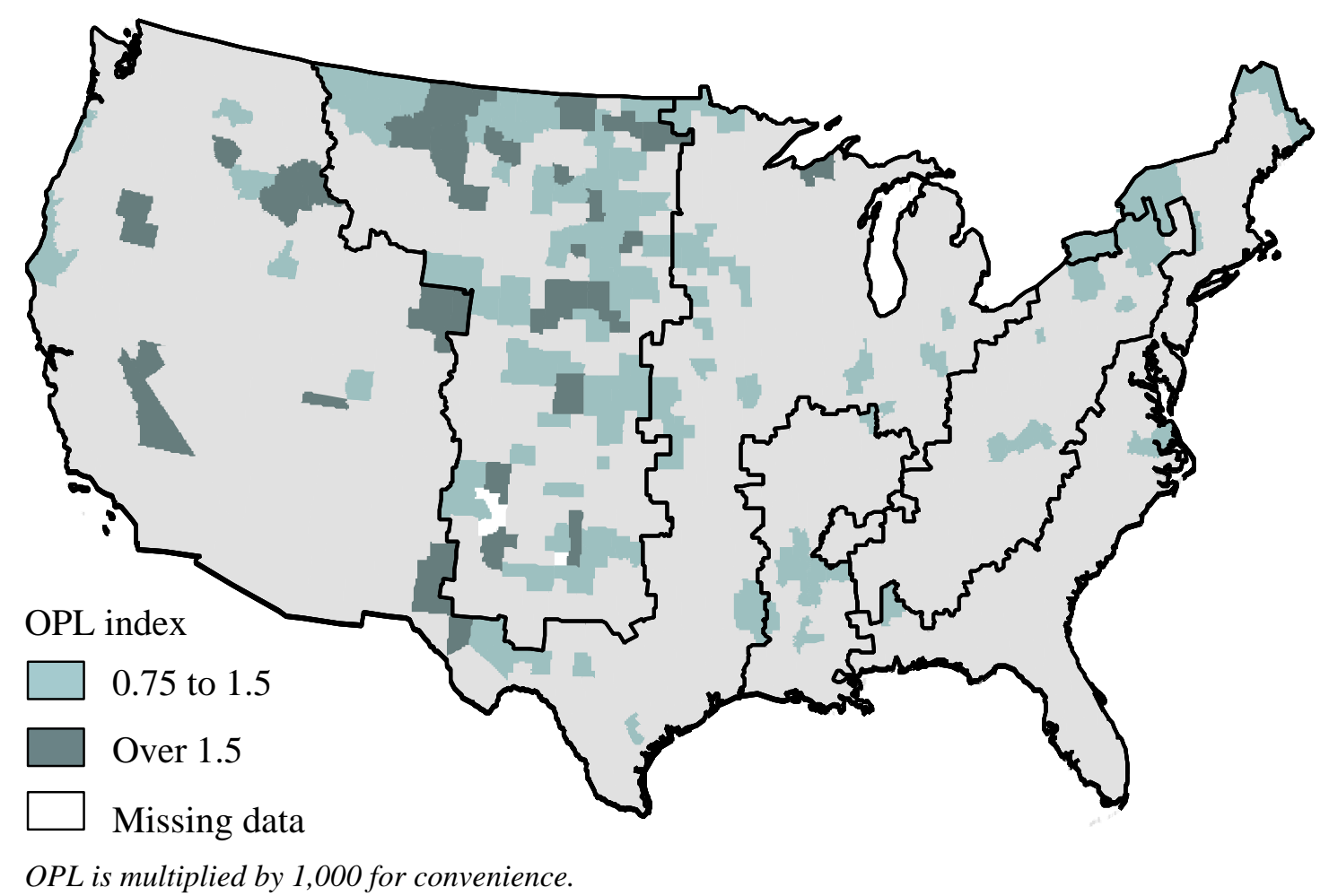

Figure 5. Regional OPL distress, 1998 

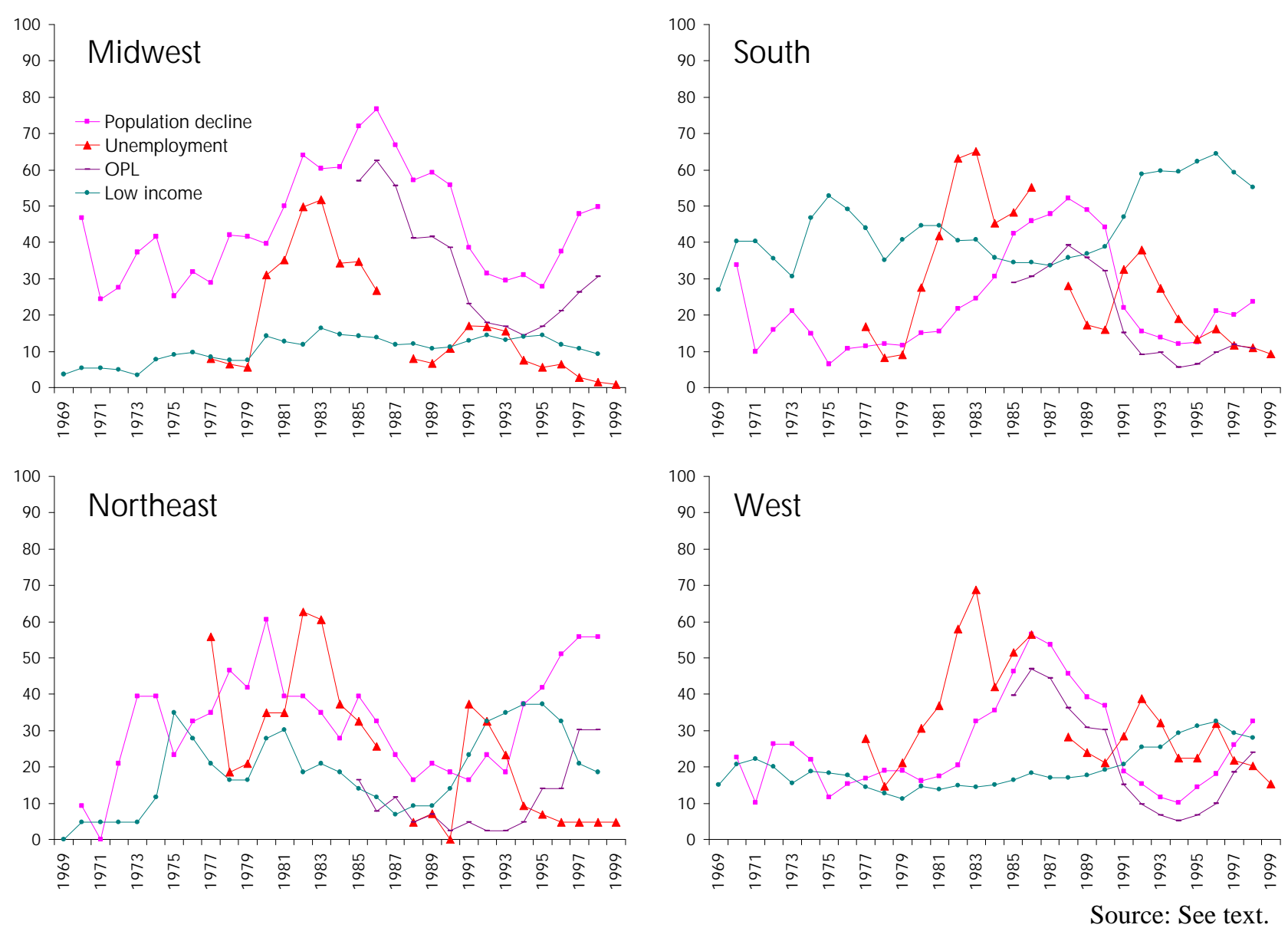

Figure 6.

Share of zones distressed in each period, four Census regions (lower 48 states only) 

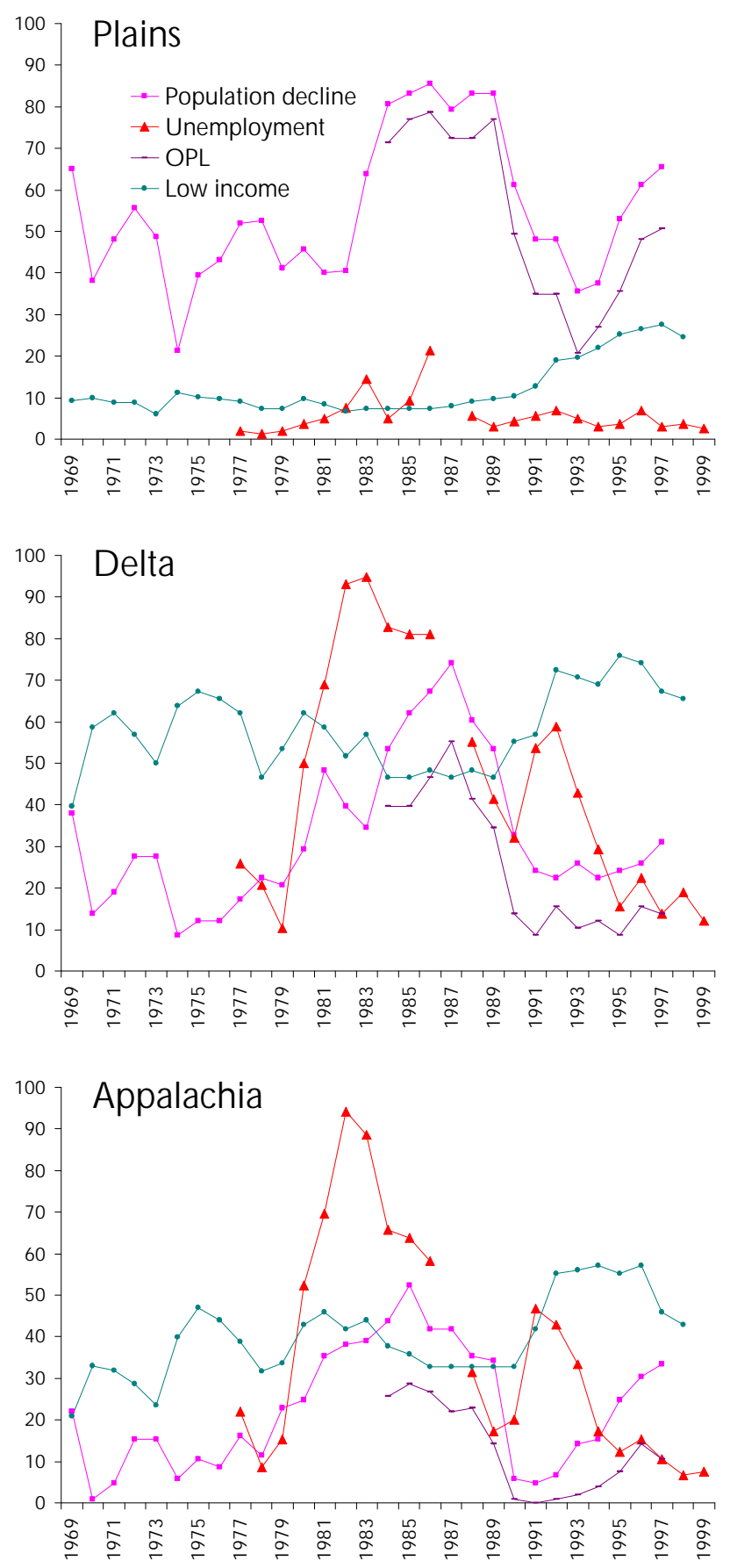

Figure. 7

Source: See text.

Share of zones distressed in each period 

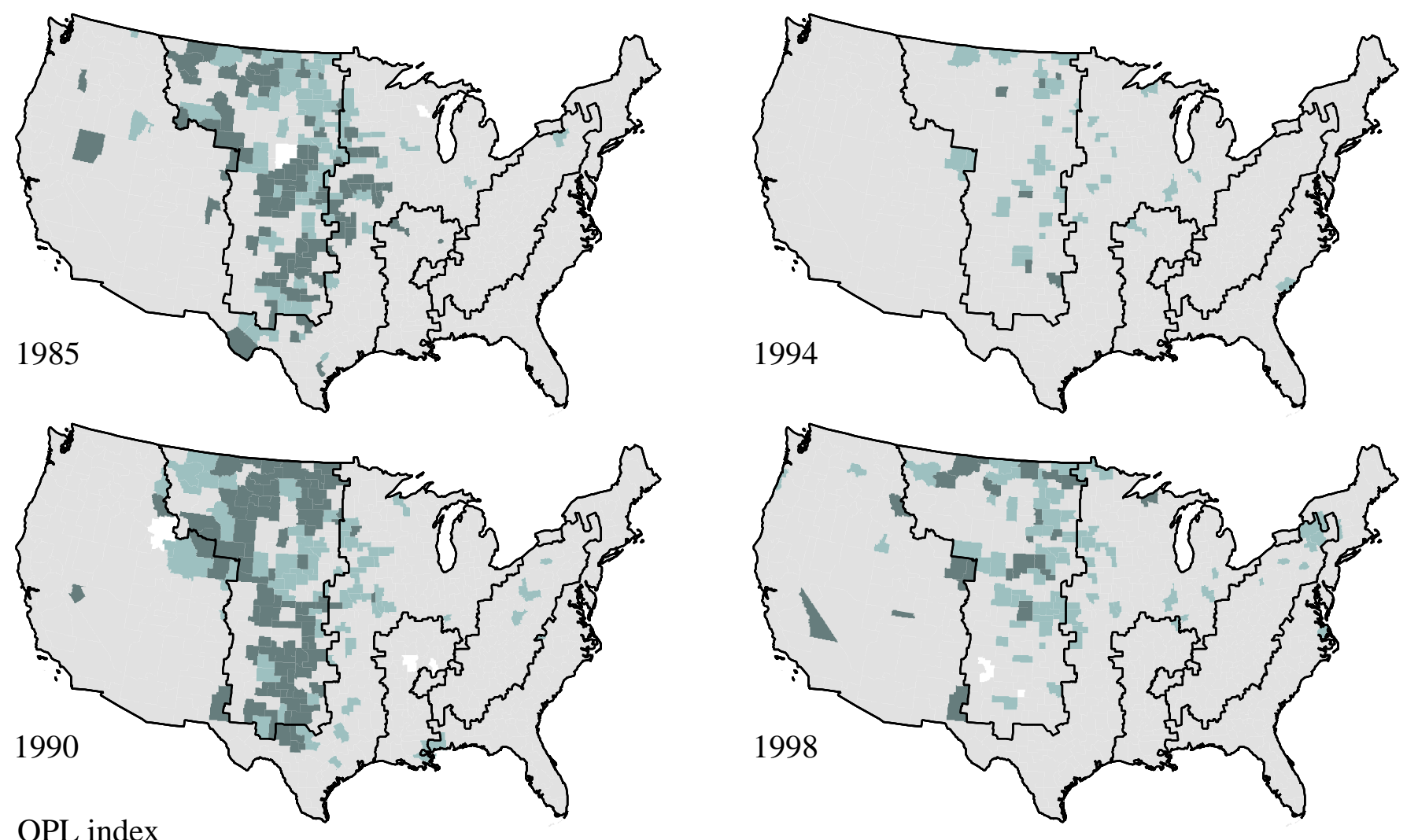

$\square .75$ to 1.5

Over $1.5 \square$ Missing data

Note: OPL is multiplied by 1,000 for convenience.

Figure 8. OPL distress only (no income or unemployment distress) 